\title{
MUC16 wt Allele
}

National Cancer Institute

\section{Source}

National Cancer Institute. MUC16 wt Allele. NCI Thesaurus. Code C71019.

Human MUC16 wild-type allele is located in the vicinity of 19q13.2 and is approximately $132 \mathrm{~kb}$ in length. This allele, which encodes mucin-16 protein, may play a role in the mediation of both cell adhesion and mucosal surface structural integrity. The gene is expressed aberrantly at elevated levels in ovarian cancers. 